\title{
AL-IQTISHADIYAH
}

Jurnal Ekonomi Syariah dan Hukum Ekonomi Syariah

E-ISSN: 2621-0274; P-ISSN: 2442-2282

Volume 7, Nomor 2, Desember 2021

\section{Implementasi Etika Bisnis Islam Dalam Perspektif Manajemen Pemasaran}

\section{Ika Rinawati', M. Yusuf Azwar Anas², \& Yuliyanti M. Manan³}

1 Fakultas Ekonomi dan Bisnis, Universitas Islam Raden Rahmat, Indonesia. E.mail : ika.rinawati@uniramalang.ac.id

2 Fakultas Ekonomi dan Bisnis, Universitas Islam Raden Rahmat, Indonesia. E.mail : yusuf.azwaranas@uniramalang.ac.id

3 Fakultas Ekonomi dan Bisnis, Universitas Islam Raden Rahmat, Indonesia. E.mail : yulianti.manan@uniramalang.ac.id

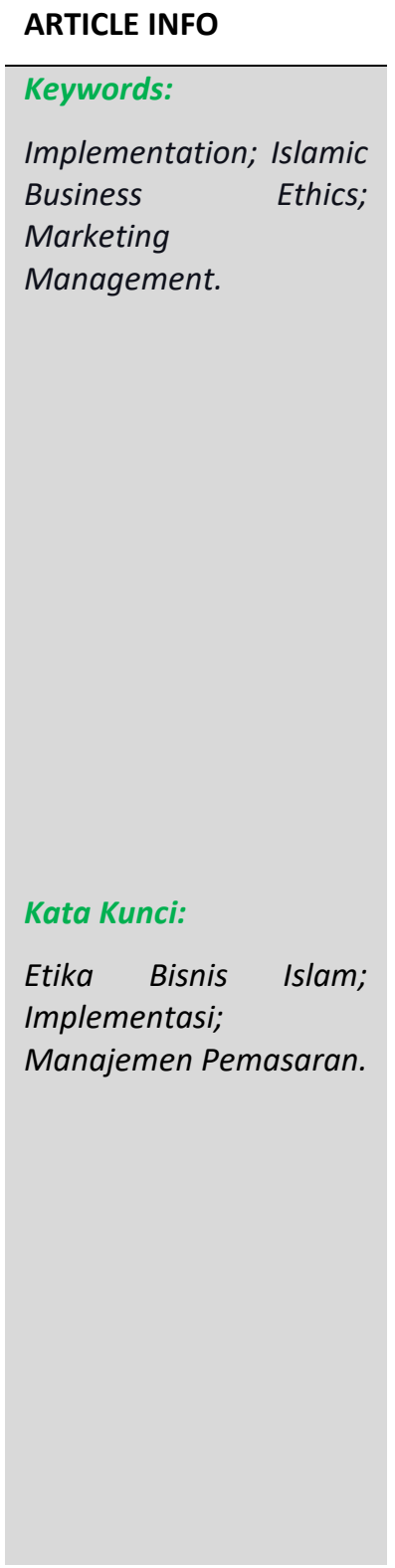

\section{ABSTRACT}

\section{ABSTRACT}

This article is a type of reference study using a narrative qualitative research method of literature study that identifies, interprets, and evaluates all literature sources related to a particular topic. The purpose of this study is to find and understand the concept of marketing with Islamic ethics. The results show that there are five marketing management concepts with Islamic ethics including: oneness in marketing management (not criticizing other products, being honest with the quality of their own products, holding on to divine values and having the intention of making profit and helping others), balance in marketing management (balanced in scales, balanced in maintaining quality, balanced in pricing, balanced between this world and the hereafter), free will in marketing management (free to innovate products in accordance with Islam), responsibility in marketing management (responsible for distribution) or sending products into the hands of consumers), virtues in marketing management (doing good and ihsan to consumers).

\section{ABSTRAK}

Artikel ini merupakan jenis kajian referensi dengan menggunakan metode penelitian kualitatif naratif studi literatur yang mengidentifikasi, menginterpretasi, dan mengevaluasi semua sumber literatur terkait topik tertentu. Tujuan penelitian ini adalah menemukan dan memahami tentang konsep pemasaran yang beretika Islam. Hasil penelitian menunjukkan bahwa Lima konsep manajemen pemasaran yang beretika Islam diantaranya adalah Keesaan dalam manajemen pemasaran (tidak mencela produk lain, jujur dengan kualitas produk sendiri, memegang teguh nilai ilahi dan memiliki niat mencari untung dan menolong orang lain), Keseimbangan dalam manajemen pemasaran (seimbang dalam timbangan, seimbang dalam menjaga kualitas, seimbang dalam penetapan harga), Kehendak bebas dalam manajemen pemasaran (bebas dalam melakukan inovasi produk yang sesuai dengan islam), Tanggung jawab dalam manajemen pemasaran (bertanggung jawab dalam hal distribusi atau mengirimkan produk ke tangan konsumen 
serta bertanggung jawab terhadap lingkungan sekitar), Kebajikan dalam manajemen pemasaran (berbuat baik dan ikhsan kepada konsumen serta memiliki kode etik dan norma etika).

\section{Pendahuluan}

Aktivitas berbisnis adalah aktifitas duniawi karena memiliki orientasi profit atau keuntungan yang bersifat materi semata, bahkan tujuan berbisnis adalah untuk mencukupi kebutuhan-kebutuhan duniawi. Bisnis yang memiliki konotasi untuk mencari keuntungan yang sifatnya pribadi sering disalah gunakan oleh para pelakunya dengan melakukan kecurangan, diantaranya adalah melakukan kecurangan dalam hal timbangan, mendikte harga, menyuap birokrat dan mematikan perusahaan lainnya. Tidak demikian dengan bisnis yang diajarkan oleh Islam, seorang pelaku bisnis Islam selalu berfikir bahwa berbisnis juga berorientasi untuk mencari keuntungan pribadi sebagaimana yang dilakukan oleh pedagang lainnya, tetapi mereka tidak menjadikan keuntungan sebagai tujuan akhir melainkan sebagai media pendukung dalam beribadah kepada Allah SWT. ${ }^{1}$

Semakin ketatnya persaingan bisnis saat ini juga merupakan salah satu penyebab semakin banyak nya persaingan yang mengarah kepada persaingan tidak sehat. Persaingan tidak sehat tersebut akhirnya memacu pelaku bisnis untuk memaksimalkan keuntungan dengan biaya produksi yang minimal, sebenarnya hal ini tidak menjadi masalah selama kegiatan bisnis tidak melanggar hukum yang berlaku. Akan tetapi pada kenyataannya tidak sedikit pelaku usaha bisnis yang mengoperasikan kegiatan bisnisnya yang mengarah pada perbuatan tindak pidana dan merugikan konsumen. Adapun dampak yang diakibatkan dari adanya bisnis curang tersebut diantaranya adalah kerugian pada produsen lain, merugikan konsumen yang memanfaatkan produknya, kerugian tersebut dapat berupa kerugian harta, benda, kesehatan atau bahkan nyawa sehingga kerugian yang ditimbulkan bersifat luas bahkan sampai merugikan perekonomian negara. Adapun contoh kasus kecurangan dalam berbisnis di Indonesia adalah kasus bisnis kosmetik seperti disampaikan oleh Mayagustina Andarini selaku Deputi Bidang Pengawasan Obat Tradisional, Suplemen Kesehatan dan Kosmetik BPOM RI, yang mengaku BPOM telah berhasil mengungkap kasus terhitung sejak Januari hingga November 2019 sebanyak 96 kasus ilegal dengan total nilai $\mathrm{Rp} 58,9$ miliar. Hal ini menunjukkan kenaikan dengan tahun lalu (www.urbanasia.com,2019).

Sedangkan yang masuk dalam kategori kecurangan dalam berbisnis adalah Pada butir 14-19 dari Resolusi PBB tersebut juga menyebutkan Kegiatan bisnis yang merugikan konsumen adalah : Pertama, Kegiatan bisnis yang tidak patuh kepada peraturan hukum. Kedua, kegiatan bisnis yang membahayakan konsumen. Ketiga, produsen yang tidak bertanggung jawab. Keempat, mempersulit konsumen dalam menentukan pilihan. Kelima, tidak ada layanan purna jual. Keenam, mengabaikan hak konsumen.

\footnotetext{
${ }^{1}$ Nana Herdiana Abdurrahman, Manajemen Bisnis Syariah \& Kewirausahaan (Bandung: CV.Pustaka Setia, 2013).
} 
Ketujuh, ketidak adilan dalam mengajukan kredit. ${ }^{2}$ Kecurangan berbisnis juga memiliki wujud berupa praktik suap yang biasa dilakukan pelaku bisnis atau pengembang kepada para pejabat daerah setempat yang bertujuan memperlancar lelang proyek atau pengadaan pada bidang tertentu. Seperti halnya Komisi Pemberantasan Korupsi (KPK) yang mengatakan, banyak perusahaan di Indonesia menjalankan praktik bisnis secara curang. Beberapa korporasi yang telah ditetapkan sebagai tersangka korupsi maupun tindak pidana pencucian uang (TPPU) sebagian besar berasal dari pelaku bisnis.

Dari pernyataan diatas maka dapat diketahui bahwa Kecurangan berbisnis merupakan dampak dari rendahnya moral dan karakter spiritual dalam menyikapi berbagai persaingan bisnis demi mendapatkan keuntungan pribadi yang lebih besar. Dari permasalahan diatas maka Islam menawarkan solusi perbaikan, bahkan ajaran tentang bisnis ini telah dipraktikkan jauh sebelum persaingan bisnis belum sekejam seperti sekarang ini. Islam merupakan agama yang universal yang ditunjukkan dengan segala ajarannya yang dapat menyentuh semua aspek kehidupan dan menyajikannya secara detail setiap perilaku berekonomi yang didalamnya termasuk perilaku berbisnis. Dalam perspektif pengusaha muslim juga mencari keberkahan usaha yaitu ketenangan hati dan memiliki pola berfikir bahwa keuntungan adalah bersifat materi dan immateri. karena keuntungan immaterial merupakan keuntungan jangka panjang tentunya adalah keuntungan untuk kepentingan akhirat. ${ }^{3}$

Bisnis yang merupakan aktifitas yang berorientasi duniawi kemudian dihubungkan dengan tuntunan syariah, dihubungkan dengan nilai nilai kelslaman yang sholeh agar kecurangan dalam berbisnis dapat terkurangi dan bahkan ditiadakan. Islam sangat menghargai aktifitas bisnis, walaupun bisnis adalah aktifitas duniawi yang didalamnya penuh dengan nafsu atau kepentingan bahkan mungkin keserakahan. Menurut Islam tidak ada yang salah dalam aktifitas bisnis terutama dalam bidang perdagangan, dalam kenyataannya seorang pelaku bisnis yang melakukan operasi kegiatan bisnis yang dilakukan dengan jujur maka akan tercatat sebagai amal kebaikan dikahirat kelak, begitu pula sebaliknya. Etika bisnis Islam perlu diimplementasikan karena etika bisnis Islam sebagai solusi atas kecurangan praktik bisnis di Indonesia. Islam melalui Rosululluloh Muhammad SAW telah mengajarkan pentingnya menerapkan etika dalam berbisnis, bahkan etika bisnis Islam yang diajarkan oleh Rosululloh telah mampu membuktikan kesuksesan Nabi Muhammad dalam bidang perdagangan hingga keluar negeri.

Pemasaran adalah kegiatan menawarkan manfaat produk guna memenuhi kebutuhan masyarakat dengan cara melakukan transaksi dengan pihak lain. ${ }^{4}$ Pemaparan implementasi etika bisnis dalam perspektif Islam akan dianalisis guna diterapkan pada

\footnotetext{
2 Hanafi Amrani, “Perlindungan Konsumen Terhadap Praktik Bisnis Curang Dan Upaya Penegakannya Melalui Sarana Hukum Pidana," Negara Hukum 6, no. 2 (2015): 188.

${ }^{3}$ Ahmad Hulaimi dkk, "Etika Bisnis Islam Dan Dampaknya Terhadap Kesejahteraan Pedagang Sapi," JEBI (Jurnal Ekonomi Dan Bisnis Islam) Volume 2, no. Nomor 1 (2017): 17-32.

${ }^{4}$ Nana Herdiana Abdurrahman, Manajemen Bisnis Syariah \& Kewirausahaan.
} 
manajemen pemasaran yang ada dalam perusahaan. Seperti penelitian yang dilakukan oleh Syaeful Bakhri, dkk. mencoba mengamati tentang tinjauan etika bisnis islam dalam strategi pemasaran dan bentuk penelitian ini adalah kajian empiris. Dalam penelitian Syaeful meneliti konsep marketing mix (produk, harga, promosi dan distribusi) dalam penerapannya pada etika bisnis Islam di pabrik tahu. ${ }^{5}$ Sedangkan dalam penelitian ini adalah menggabungkan konsep pemasaran dengan konsep yang diajarkan dalam teori etika bisnis Islam. Sehingga ada satu konsep yang akan dibangun disini adalah konsep tentang manajemen pemasaran yang beretika Islam.

Pada penelitian lain yang dilakukan oleh Ramdania memiliki tujuan penelitian yaitu mendiskusikan konsep etika perilaku pemasaran dan kepuasan konsumen dalam perspektif ekonomi Islam. ${ }^{6}$ Berbeda hal nya dengan penelitian ini yang memiliki tujuan yaitu menemukan dan memahami tentang konsep pemasaran yang beretika Islam.

Penelitian dengan judul Implementasi etika bisnis Islam dalam strategi promosi juga dilakukan oleh Farma, dalam hal ini mengamati asuransi takaful banda aceh dalam menerapkan konsep promosi nya (advertising, personal selling, sales promotion dan publicity) didalam konsep etika bisnis Islam (tawhid, adl, ikhtiyar, fard dan ihsan). ${ }^{7}$ Sedangkan dalam penelitian ini tidak terbatas pada promosi melainkan keseluruhan kegiatan pemasaran.

Dari analisis tersebut diharapkan akan semakin jelas wajah implementasi bisnis Islam ketika diterapkan pada manajemen pemasaran pada perusahaan. Sehingga persaingan tidak sehat dalam berbisnis dan keserakahan akan keuntungan materi bisa diminimalisir bahkan dihapuskan agar tercipta simbiosis mutualisme antara perusahaan dan konsumen serta meningkatkan pertumbuhan perekonomian negara karena didukung dengan meningkatnya produk domestik bruto (PDB).

\section{Etika bisnis Islam dan Implementasinya}

\section{Etika Bisnis Islam}

Etika adalah Sebuah disiplin ilmu yang berisi patokan patokan tentang kebaikan dan keburukan dan yang bermanfaat atau tidak bermanfaat. ${ }^{8}$ Menurut webster dictionary, secara etimologis, etika adalah suatu disiplin ilmu yang menjelaskan sesuatu yang baik dan yang buruk, mana tugas atau kewajiban moral atau bisa juga

\footnotetext{
5 Leliya dan Latip Purnama Syaeful Bakhri, "TINJAUAN ETIKA BISNIS ISLAM DALAM STRATEGI PEMASARAN HOME INDUSTRI TAHU SARI RASA," Al-Mustashfa Vol. 3, no. No. 2 (2018): 284-99.

${ }^{6}$ Wida Ramdania, “Etika Bisnis Islam Pada Perilaku Pemasaran Dan Kepuasan Konsumen," Asy-Syari'ah 22, no. 2 (2021): 275-90, https://doi.org/10.15575/as.v22i2.8259.

7 Junia Farma and Khairil Umuri, "Implementasi Etika Bisnis Islam Dalam Strategi Promosi Produk Asuransi Takaful," Cakrawala: Jurnal Studi Islam 15, no. 1 (2020): 19-29, https://doi.org/10.31603/cakrawala.v15i1.3268.

${ }^{8}$ Muhammad, Etika Bisnis Islam (yogyakarta: UPP AMP YKPN, 2002).
} 
mengenai kumpulan prinsip atau nilai moral. ${ }^{9}$ Bisnis Islami adalah sebagai serangkaian aktivitas bisnis yang didalamnya terdapat pembatasan tentang cara memperoleh keuntungan dan pendayagunaan hartanya (ada aturan halal dan haramnya). ${ }^{10}$

Dengan demikian secara filosofis etika Islam mendasarkan diri pada nalar ilmu dan agama untuk menilai suatu perilaku manusia. Landasan penilaian ini dalam praktik kehidupan dimasyarakat sering kita temukan, bahwa secara agama dinilai baik atau buruk atau jahat sering diperkuat dengan alasan alasan dan argument argumen ilmiah atau ilmu dalam agama Islam yang telah berabad abad dinyatakan dalam agama maka dapat dibenarkan secara ilmiah oleh orang yang mencari kebenaran. Bahkan sering dalam perjalanan filosof dan para ilmuan telah banyak membuktikan kebenaran agama Islam secara ilmiah untuk berbagai bidang dan aspek paradigma ilmu pengetahuan termasuk ilmu pengetahuan perilaku manusia dalam hubungannya dengan manusia dan alam sekitar. ${ }^{11}$

Menurut Fauroni (2002), kata bisnis sendiri telah disebutkan di dalam al quran dengan sebutan al tijarah, isytara dan al-ba'i tadayantum dan yang paling sering disebutkan adalah al tijarahi atau tijaraha yang bermakna berdagang. Menurut arRaghib al Asfahani dalam al Mufradat fi gharib al-Qur'an, at-tijarah memiliki arti pendayagunaan kekayaan dan tujuan memperoleh profit. ${ }^{12}$ Nilai etik inilah yang mendorong manusia menjadi sosok individu yang mulia dan senantiasa melakukan tindakan yang menyejukkan hati misalkan keterbukaan, keseimbangan dan kesenangan. ${ }^{13}$

\section{Implementasi Etika Bisnis Islam}

Semakin banyaknya kecurangan berbisnis yang menyebabkan timbulnya kegiatan bisnis yang tidak diperkenankan dalam islam. Maka konsep implementasi etika bisnis disarankan agar diterapkan dalam aktivitas bisnis sehari hari, dengan harapan bahwa bisnis yang dikelola lebih bermanfaat dan membawa berkah atau manfaat bagi pelaku bisnis dan bagi pengguna atau konsumen. Jika konsep implementasi etika bisnis ini diterapkan dalam kegiatan bisnis maka bisnis tersebut akan menciptakan kesejahteraan bersama sehingga sesuai dengan tujuan Islam turun ke bumi yaitu rohmatan lil alamin. ${ }^{14}$

\footnotetext{
${ }^{9}$ Sofyan Harahap, Etika Bisnis Dalam Perspektif Islam (Jakarta: Salemba Empat, 2011).

10 muhammmad Ismail Yusanto dan Muhammad Karebet Widjajakusuma, Menggagas Bisnis Islam (Jakarta: Gema Insani, 2002).

${ }^{11}$ Muslich, Bisnis Syariah. Perspektif Muamalah Dan Manajemen (Yogyakarta: UPP STIM YKPN, 2007).

${ }^{12}$ Ahmad Hulaimi dkk, “Etika Bisnis Islam Dan Dampaknya Terhadap Kesejahteraan Pedagang Sapi."

${ }^{13}$ Erly Juliyani, “Etika Bisnis Dalam Perspektif Islam,” Jurnal Ummul Qura Vol VII, no. No.1 (2016): 6374.

${ }^{14}$ Lalu Muh Shabiran dkk, "Etika Bisnis Pedagang Pada Jual Beli Telepon Genggam Bekas Ditinjau Dari Perspektif Ekonomi Islam Di Kecamatan Selong Kabupaten Lombok Timur," Iqtishoduna Vol. 6, no. No. 2 (2017): 190-221.
} 
Adapun implementasi etika bisnis Islam diantaranya adalah :

a. Konsep Keesaan dalam Etika Bisnis

Konsep ini merupakan hubungan vertical manusia dengan Tuhannya, didalamnya terdapat proses penghambaan yang murni dan tulus akan pelaksanaan tentang perintah dan larangan dari Tuhannya. Menurut Djakfar (2012), Konsep keesaan ini memiliki tujuan penanaman keimanan praktisi bisnis kepada kesatuan (keesaan) Tuhannya. ${ }^{15}$

Muslich (2004) Mengungkapkan bahwa dasar hukum berbisnis dalam Islam adalah al Qur'an dan al Hadits. ${ }^{16}$

Konsep keesaan bukan hanya mengajarkan agar pelaku bisnis hanya memikirkan ibadah dengan tuhannya tetapi dengan bekal kedekatan tersebut manusia diharapkan memiliki etos kerja yang tinggi dan kerja keras untuk mencari sumber penghidupan seperti firman Allah:

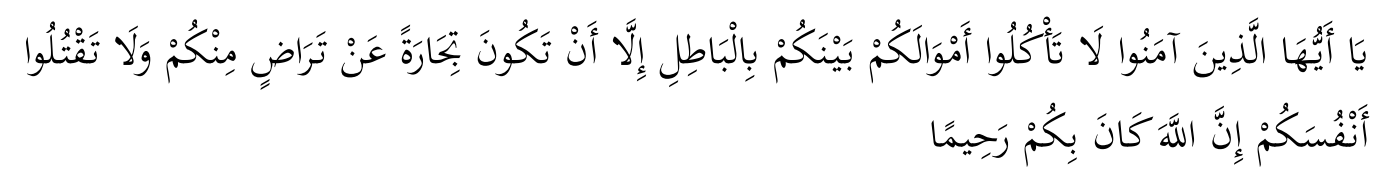

Artinya: "Hai orang-orang yang beriman, janganlah kamu saling memakan harta sesamamu dengan jalan yang batil, kecuali dengan jalan perniagaan yang berlaku dengan suka sama-suka di antara kamu. Dan janganlah kamu membunuh dirimu; sesungguhnya Allah adalah Maha Penyayang kepadamu." (An Nisa 4: 29)

Dalam surat yang lain juga disebutkan

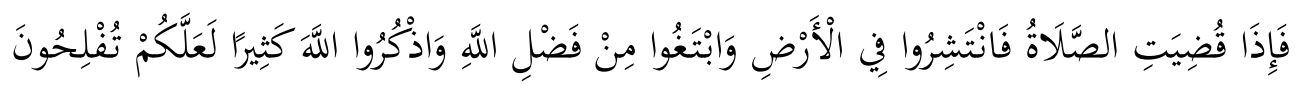

Artinya: "Apabila telah ditunaikan shalat, maka bertebaranlah kamu di muka bumi; dan carilah karunia Allah dan ingatlah Allah banyak-banyak supaya kamu beruntung." (Al Jumuah, 62:10)

Dalam firman Allah diatas dijelaskan bahwa tidak ada larangan dalam aktivitas berdagang tetapi jangan sampai aktifitas perdagangan melalaikan manusia dari aktifitas beribadah kepada Allah. Allah juga melarang melakukan kegiatan memakan harta dengan jalan yang bathil dimana kegiatan ini biasa dilakukan dalam aktifitas bisnis agar keuntungan yang didapat semakin banyak.

Adapun karakter pengusaha muslim yang menerapkan keesaan dalam prinsip hidupnya yaitu selalu menjalankan perintahNya dan menjauhi laranganNya, karakter tersebut diantaranya adalah tidak melakukan diskriminasi atau tidak membeda bedakan klien dari segi materinya atau latar belakang pendidikannya.

\footnotetext{
${ }^{15}$ Erly Juliyani, "Etika Bisnis Dalam Perspektif Islam."

16 Galuh Anggraeny, "Pembelajaran Dan Implementasi Etika Bisnis Islam: Studi Pada Mahasiswa Akuntansi Syariah IAIN Surakarta," Academica Vol. 1, no. No. 2 (2017): 231-42.
} 
Dia akan melakukan hal yang sama sama baik tidak peduli dimanapun dia berada, baik di masjid atau di tempat kerja nya. Konsep amanah adalah mampu menjaga titipan Allah serta memanfaatkannya untuk kebaikan kemudian mempertanggungjawabkan nya. ${ }^{17}$

b. Konsep Keseimbangan dalam Etika Bisnis

Pelaku bisnis hendaknya menerapkan kesetaraan dalam ekonomi dan social baik terhadap dirinya maupun terhadap orang lain atau konsumennya. ${ }^{18}$

Dijelaskan dalam firmanNya dalam surat al Hud ayat 85 :

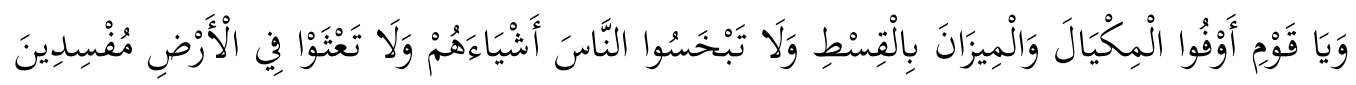

Artinya: "Dan Syu'aib berkata: "Hai kaumku, cukupkanlah takaran dan timbangan dengan adil, dan janganlah kamu merugikan manusia terhadap hak-hak mereka dan janganlah kamu membuat kejahatan di muka bumi dengan membuat kerusakan."

Dari penjelasan ayat diatas disebutkan bahwa seorang pengusaha muslim harus melakukan tindakan adil atau setara dalam transaksi nya. Hal ini dilakukan karena Islam tidak menginginkan adanya kedzaliman yang dilakukan oleh pelaku bisnis, sebaliknya Islam sangat menginginkan adanya kemaslahatan umat dalam setiap bisnis yang dilakukan. Kebijakan kebijakan bisnis juga harus mengupayakan keseimbangan antara nilai nilai keduniawian dan nilai nilai ukhrawi, yang pada akhirnya akan memperkuat daya tahan dan kehidupan jangka panjang bisnis itu sendiri. ${ }^{19}$

Landasan keadilan didalam Islam merupakan landasan pokok seorang muslim dalam bertindak dan bergaul antara hubungan manusia secara vertical dengan Rabb nya, hubungan manusia secara horisontal yaitu hubungan manusia dengan sesamanya dan lingkungannya. ${ }^{20} \mathrm{Hal}$ ini dapat dibuktikan pada firman Allah dalam QS Al Hadid 25 yang artinya :

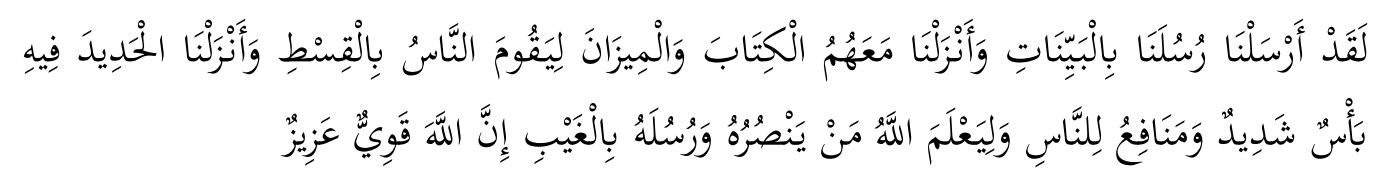

\footnotetext{
${ }^{17}$ Muhammad, Etika Bisnis Islam.

${ }^{18}$ Siti Nur Latifah, "Pengaruh Penerapan Etika Bisnis Muhammad Saw Terhadap Customer Retention Dan Dampaknya Terhadap Peningkatan Pendapatan Internal Stakeholders, (STUDI KASUS PADA UNIT USAHA PENJUALAN DAN JASA PENGGILINGAN DAGING PELITA JAYA JEMBER)," Iqtishoduna: Jurnal Ekonomi Islam Vol. 8, no. No. 1 (2019): 97-140.

${ }^{19}$ Riyanto Sofyan, Bisnis Syariah Mengapa Tidak. Pengalaman Penerapan Pada Bisnis Hotel (Jakarta: PT. Gramedia Pustaka Utama), 2011).

20 Houda dan Mohsen Debabi Zarrad, "ISLAMIC MARKETING ETHICS: A LITERATURE REVIEW," International Journal of Management Research \& Review 5, no. 2 (2015): 60-66.
} 
Artinya: "Sesungguhnya Kami telah mengutus rasul-rasul Kami dengan membawa bukti-bukti yang nyata dan telah Kami turunkan bersama mereka Al Kitab dan neraca (keadilan) supaya manusia dapat melaksanakan keadilan. Dan Kami ciptakan besi yang padanya terdapat kekuatan yang hebat dan berbagai manfaat bagi manusia, (supaya mereka mempergunakan besi itu) dan supaya Allah mengetahui siapa yang menolong (agama)Nya dan rasul-rasul-Nya padahal Allah tidak dilihatnya. Sesungguhnya Allah Maha Kuat lagi Maha Perkasa."

Implementasi ajaran keadilan atau keseimbangan adalah hubungan simbiosis mutualisme dalam kegiatan bisnis. Sehingga menimbulkan persetaraan antara hak dan kewajiban kedua belah pihak. ${ }^{21}$

c. Konsep kehendak bebas dalam etika bisnis

Manusia terlahir dengan nikmat Allah SWT yang sangat besar, diantaranya adalah karena manusia memiliki kemampuan berfikir dan memiliki kebebasan dalam memanfaatkannya untuk menentukan keputusan yang akan dia ambil dalam hidupnya. Menurut Islam, manusia memiliki kebebasan dalam bertindak yang diperlukan untuk mengelola kebebasan, pemanfaatan tersebut harus mewujudkan kesejahteraan bersama serta Islam memberikan batasan terhadap kebebasan manusia. ${ }^{22}$

Kebebasan dalam diri manusia bersifat terbatas dan kebebasan yang tak terbatas adalah milik Allah SWT.

Oleh karena itu, bagi setiap orang mukmin, kebebasan dalam dirinya senantiasan dibimbing oleh aturan yang didasarkan pada ketentuan ketentuan Tuhan yang dicontohkan dalam sikap Rosululloh. ${ }^{23}$ Kebebasan berpikir yang memiliki konsekuensi baik tentunya akan membawa manfaat bagi diri sendiri maupun masyarakat, yaitu ketika manusia telah menggunakan kreatifitasnya dengan memanfaatkan sumber daya alam untuk pemasok bisnisnya dengan cara yang diridhoi oleh Allah. Sedangkan kebebasan berpikir yang memiliki konsekuensi buruk adalah jika menusia menggunakan kebebasannya dalam berkreasi dan memanfaatkan sumber daya alam dengan cara yang terlarang dan mengandung dosa.

d. Konsep tanggung jawab dalam etika bisnis

Segala kegiatan bisnis yang dilakukan akan dituntut pertanggungjawabannya, Maka dari itu ia tidak bisa melakukan tindakan bisnis yang tidak etis dengan alasan adanya tekanan dari dunia bisnis atau tindakan tidak etis tersebut sudah

\footnotetext{
${ }^{21}$ Muslich, Bisnis Syariah. Perspektif Muamalah Dan Manajemen.

22 Erly Juliyani, "Etika Bisnis Dalam Perspektif Islam."

${ }^{23}$ H Djakfar, Etika Bisnis: Menangkap Spirit Ajaran Langit Dan Pesan Moral Ajaran Bumi. (Jakarta: Penebar PLUS+., 2012).
} 
menjadi budaya dikalangan pembisnis.Setiap manusia adalah kholifah atau pengemban amanat Allah, dan di hari akhir nanti manusia harus mempertanggungjawabkan amanat yang sudah diberikan kepada dirinya. Manusia dapat mengambil manfaat dari Sumber Daya Alam yang telah disediakan oleh Allah dan setiap individu mampu memperoleh keuntungan tersebut sesuai dengan kemampuannya (kapabilitas-kapasitas) serta keterampilan, intelektualitas dan talenta yang berbeda beda. ${ }^{24}$

Kemuliaan dalam berbisnis dapat dilihat pada penerapan program - program ramah lingkungan yang kadang membutuhkan investasi yang besar, namun ternyata penghematan yang didapat pada tahun tahun mendatang dapat mengembalikan investasi awal dalam kurun waktu yang cepat sehingga keuntungan jangka panjang menjadi lebih tinggi. Bagi siapa saja yang menyakini bahwa syariah adalah metode yang sempurna dan paripurna maka ini menjadi solusi satu satunya yang akan membawa kepada kesuksesan dunia dan akhirat. ${ }^{25}$

Manusia memiliki peran sebagai pemegang amanah saat mengelola sumber daya yang ada di bumi ini dan kelak di akhirat harus mempertanggung jawabkan kepada Allah sebagai sang pemilik mutlak. Selain itu, Manusia selaku pelaku bisnis juga memiliki kewajiban untuk mempertanggung jawabkan di dunia, produk yang dijualnya kepada para pihak terkait (konsumen, pemasok, pemegang saham dan sebagainya).

e. Konsep kebajikan dalam etika bisnis

Menurut al Ghazali, terdapat 6 bentuk kebajikan yaitu: ${ }^{26}$ Mengambil keuntungan sedikit mungkin jika pembelinya merupakan orang yang sangat membutuhkan dan tidak mampu membeli dengan harga pasaran, membeli barang dari orang miskin dengan harga sedikit lebih tinggi dari harga umum, memberikan kelonggaran waktu kepada peminjam yang mengalami kesulitan keuangan, menerima retur barang jika tidak sesuai dengan permintaan konsumen, membayar hutang sebelum jatuh tempo adalah hal yang lebih baik, penjual memberikan kelonggaran waktu bagi konsumen yang membeli dengan cara kredit dan tidak mampu membayar sesuai waktu yang telah ditentukan.

Berlaku ikhsan dalam berbisnis adalah melakukan kegiatan bisnis dengan niat beribadah dan menciptakan kemaslahatan umat dan lingkungan. ${ }^{27}$ Konsep bisnis syariah yang menyeluruh dan dan lengkap berdasarkan syariah ini seyogyanya diimplementasikan dengan usaha usaha yang kaffah (menyeluruh / komprehensif) dan ihsan (professional dan bijaksana).

\footnotetext{
${ }^{24}$ Riyanto Sofyan, Bisnis Syariah Mengapa Tidak. Pengalaman Penerapan Pada Bisnis Hotel.

${ }^{25}$ Riyanto Sofyan.

${ }^{26}$ Muhammad, Etika Bisnis Islam.

${ }^{27}$ Muslich, Bisnis Syariah. Perspektif Muamalah Dan Manajemen.
} 
Implementasi harus dimulai dengan memberikan pemahaman kepada seluruh berbagai pihak yang mendukung terlaksananya lembaga bisnis syariah tersebut terhadap paradigma yang Islami dan posisinya dalam tatanan masyarakat yang ada (waqi'i). Hal ini diperlukan untuk menghindari masalah yang terjadi diantara para pihak terkait. Maka seyogyanya implementasi tersebut harus dilaksanakan dengan cara yang bijaksana dengan berpegang pada ayat ayat qauliah (al quran dan al hadits) dan juga membaca ayat ayat kauniah (hukum hukum dan fenomena yang ada dalam bisnis yang sifatnya sunnatullah. ${ }^{28}$

\section{Metode Penelitian}

Jenis penelitian ini adalah kualitatif naratif dan merupakan studi literatur yang mengidentifikasi, menginterpretasi, dan mengevaluasi semua sumber literatur terkait topik tertentu (Hart, 1998). Analisa dalam kajian ini menggunakan metode metasintesis, yaitu proses mengintegrasi data untuk memperoleh teori-teori serta pemahaman-pemahaman baru yang lebih mendalam dan menyeluruh. ${ }^{29}$ Adapun langkah-langkah yang ditempuh dalam penelitian studi literatur yaitu: ${ }^{30}$ Menyusun pertanyaan penelitian, Mengumpulkan dan menyeleksi literatur terkait, Mensintesa temuan, Mengontrol kualitas sintesa, Menyusun laporan akhir. Teori induk yang dipakai adalah teori dalam buku karya Muhammad. 2002. Etika Bisnis Islam. yogyakarta: UPP AMP YKPN serta didukung oleh buku lain dan jurnal baik nasional maupun internasional.

\section{Implementasi Etika Bisnis Islam dalam Manajemen Pemasaran}

Pemasaran merupakan unsur vital dalam dunia bisnis karena pemasaran berkaitan dengan proses mengidentifikasi dan memenuhi kebutuhan manusia maupun masyarakat. Menurut American marketing asosiation, pemasaran adalah suatu fungsi organisasi dan seperangkat proses untuk menciptakan, mengomunikasikan, dan menyerahkan nilai kepada konsumen, serta mengelola hubungan baik dengan konsumen melalui cara yang menguntungkan. Organisasi dan para pemilik saham. ${ }^{31}$ Sedangkan manajemen pemasaran dalam perspektif Islam adalah semua kegiatan yang dilakukan dalam bisnis yang berupa kegiatan penciptaan nilai (value creating activities) yang memungkinkan siapapun yang melakukan dapat tumbuh dan mampu

\footnotetext{
${ }^{28}$ Riyanto Sofyan, Bisnis Syariah Mengapa Tidak. Pengalaman Penerapan Pada Bisnis Hotel.

${ }^{29}$ A. \& Hammond Perry, “N. Systematic Reviews: The Experience of a PhD Student.," Psychology Learning and Teaching 2, no. 1 (2002).

${ }^{30}$ Siswanto, "Systematic Review Sebagai Metode Penelitian Untuk Mensintesis Hasil-Hasil Penelitian," Buletin Penelitian Sistem Kesehatan 13, no. 4 (2010).

${ }^{31}$ Zainal veithzal rivai. Dkk, Islamic Marketing Management "mengembangkan Bisnis Dengan Hijrah Kepemasaran Islami Mengikuti Praktik Rosulullah, (Jakarta: PT Bumi Aksara, 2016).
} 
mendaya gunakan kemanfaatannya berlandaskan pada kejujuran, keadilan, keterbukaan yang sesuai dengan nilai Islam. ${ }^{32}$

Terkait dengan manajemen pemasaran Islami, untuk mencapai optimalisasi kinerja, pemasaran produk, organisasi perlu membentuk struktur khusus yang menjalankan tugas pemasaran. Orang atau kelompok orang yang memiliki kewenangan atas organisasi akan melimpahkan wewenangnya kepada orang lain atau sekelompok orang untuk menajalankan tugas dalam hal strategi dan teknis pemasaran pada organisasi tersebut. Dalam perkembangan kegiatan bisnis pada saat ini pemasaran termasuk strategi bisnis yang menunjukkan adanya proses penawaran produk pada hubungan antara produsen kepada konsumen. Oleh karena itu menurut ajaran Islam, kegiatan pemasaran harus dilandasi oleh nilai-nilai Islami yang dijiwai dengan semangat beribadah kepada Allah SWT serta memiliki tujuan untuk kesejahteraan bersama bukan hanya untuk kesejahteraan pribadi. ${ }^{33}$

Adapun implementasi bisnis Islam dalam manajemen pemasaran adalah sebagai berikut :

1. Analisis keesaan dalam manajemen pemasaran

Islam telah mengajarkan untuk melakukan promosi yang beretika dan tidak melakukan eksploitasi terhadap label gen (perempuan) untuk mendukung promosinya. Hal ini sangat banyak dilakukan oleh marketer saat ini. Oleh karena itu Islam mengajarkan tentang etika promosi seperti halnya yang dilakukan oleh rosulullah saw, Oleh karena itu seorang marketing yang menerapkan prinsip keesaan adalah: ${ }^{34}$

a. Tidak mencela produk pedagang lainnya

b. Jujur dengan kualitas produk

c. Memegang teguh nilai llahi, kegiatan berbisnis harus menyadarkan manusia bahwa manusia merupakan makhluk bertuhan sehingga manusia selalu berbuat sesuai dengan ketentuan Allah, terutama dalam hal jual beli, tidak hanya mengejar keuntungan tetapi disertai dengan

d. Niat untuk menolong orang lain, berniat baik dalam melakukan bisnis.

Selain untuk menjadi yang terbaik, berbisnis juga harus dapat menjadi lahan untuk bermanfaat terhadap orang lain, menjaga nama baik, seperti halnya Rosulullah juga selalu menjaga nama baik sehingga banyak sekali yang ingin bekerja sama dengan beliau. Islam juga mengajarkan untuk melakukan promosi dengan kejujuran akan kualitas produk serta memberikan kesempatan kepada konsumen untuk

\footnotetext{
32 Zainal veithzal rivai. Dkk.

33 Nurul dan Eriza Yolanda Maldina Mubarok, "Strategi Pemasaran Islami Dalam Meningkatkan Penjualan Pada Butik Calista," I-Economic Vol.3, no. No 1 (2017): 73-92.

${ }^{34}$ Zainal veithzal rivai. Dkk, Islamic Marketing Management "mengembangkan Bisnis Dengan Hijrah Kepemasaran Islami Mengikuti Praktik Rosulullah,.
} 
memberikan keputusan yang rasional terhadap produk kita berdasarkan kebenaran informasi yang diperoleh. ${ }^{35}$

2. Analisis keseimbangan dalam manajemen pemasaran

Pelaku bisnis harus mampu berlaku adil dalam melindungi konsumennya, adil yang bisa dilakukan misalnya adalah adil dalam menimbang dan menakar sehingga tidak merugikan pembelinya. Allah SWT memerintahkan kepada kaum muslimin untuk memperhatikan kehidupan dunia dan akhirat. Berbisnis untuk urusan dunia harus seimbang dengan urusan akhirat, sehingga berbisnis mampu menjadi media dalam menambah keimanan pelakunya. Bersikap seimbang dalam memberikan takaran sebagaimana tertulis dalam firman Allah swt dalam surat al isra' 35:

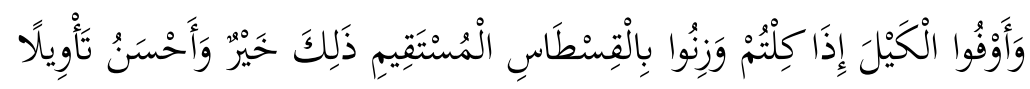

Artinya: "Dan sempurnakanlah takaran apabila kamu menakar, dan timbanglah dengan neraca yang benar. Itulah yang lebih utama (bagimu) dan lebih baik akibatnya."

Melalui ayat tersebut di atas Allah memerintahkan agar kita selalu bersikap adil, seimbang dan tidak berat sebelah dalam menimbang agar tidak terjadi tindak pendholiman yang dilakukan oleh marketer kepada konsumen. ${ }^{36}$ Oleh karena itu seorang marketing yang menerapkan prinsip keseimbangan adalah:

a. Seimbang dalam timbangan

Disamping itu Allah juga memberikan perintah untuk menyempurnakan takaran atau timbangan karena dengan melakukan tindakan penyempurnaan maka akan menimbulkan kesejahteraan, ketentraman bagi marketer dan konsumen serta akan berdampak pada kelangsungan kegiatan bisnis yang bersifat jangka panjang.

b. Seimbang dalam menjaga kualitas

c. Seimbang dalam penentuan harga

Analisis keseimbangan yang bisa dilakukan oleh pelaku bisnis Islam selanjutnya adalah keseimbangan pada harga yang berlaku, harga hendaknya mencerminkan keuntungan yang standart dan sesuai dengan manfaat yang diberikan oleh suatu produk. ${ }^{37}$ Dengan kata lain bahwa manifestasi keadilan

\footnotetext{
${ }^{35}$ Munib Siddiqui dkk, "Halal Marketing (Islamic Principles of Marketing and Marketing Mix Model in Islam)," Advances in Islamic Business Vol 3, no. No 5 (2017): 289-98.

36 Moh. Toriquddin, “Etika Pemasaran Perspektif Al-Qur'an Dan Relevansinnya Dalam Perbankan Syari'ah," De Jure, Jurnal Syariah Dan Hukum Volume 7, no. Nomor 2 (2015): 116-25.

${ }^{37}$ Isnaini harapan Dkk, Hadis Hadis Ekonomi (Jakarta: kencana, 2015).
} 
sosial Islam menuntut regulasi pasar untuk menjamin akan posisi harga harus tetap dalam keadaan yang adil. ${ }^{38}$

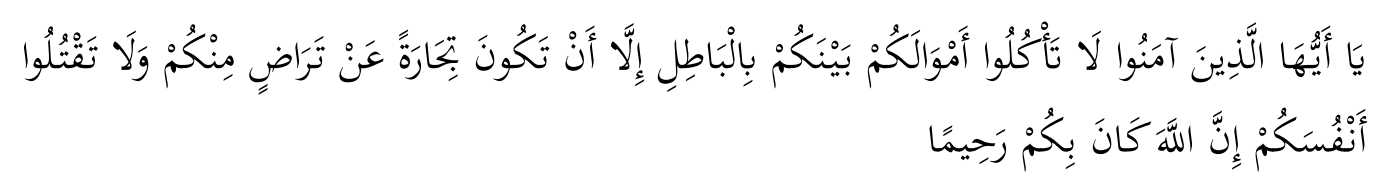

Artinya: "Hai orang-orang yang beriman, janganlah kamu saling memakan harta sesamamu dengan jalan yang batil, kecuali dengan jalan perniagaan yang berlaku dengan suka sama-suka di antara kamu. Dan janganlah kamu membunuh dirimu; sesungguhnya Allah adalah Maha Penyayang kepadamu." (Q.S An Nisa ayat 29).

Dalam hadits Nabi Muhammad yang diriwayatkan oleh al nawawi 2: 270, "Nabi melarang menaikkan harga dalam kompetisi", dalam hadits tersebut dapat dipahami bahwa untuk menghilangkan ketidak adilan ini maka pelaku bisnis harus menyadari bahwa ada tanggung jawab moral yang lebih tinggi dibumi ini jika dibandingkan dengan selalu memperbanyak laba demi keuntungan pribadi. ${ }^{39}$ Islam tidak mengharuskan melakukan pembayaran dalam bentuk uang melainkan pembayaran atas harga bisa dilakukan dengan negosiasi dengan beberapa komoditas sebagai gantinya. Islam juga tidak melarang kontrol harga jika itu untuk kebutuhan pasar dan distribusi. ${ }^{40}$

3. Analisis kehendak bebas dalam manajemen pemasaran

Pelaku bisnis diberikan kebebasan untuk menciptakan suatu produk untuk mengembangkan bisnisnya. Oleh karena itu seorang marketing yang menerapkan kehendak bebas adalah bebas melakukan inovasi produk baru.

Manusia diberikan kebebasan dalam melakukan tindakan atau perbuatan guna mewujudkan kesejahteraannya, serta dalam hal mengeksplore seluruh kekuatan yang menjadi sumber daya dirinya yang diberikan oleh Allah SWT, tetapi kehendak bebas yang diberikan oleh Islam tetap dibatasi oleh nilai nilai Islam. ${ }^{41}$ Tentunya produk baru tersebut akan dinilai oleh konsumen tentang kualitasnya, manfaatnya dan atribut yang dibawanya. Sebelum mengembangkan produk baru, perlu diawali dengan melakukan tabayyun atau riset. Hal tersebut perlu dilakukan untuk menyesuaikan produk baru dengan kebutuhan pasar atau mengenal pasar mana yang menjadi target bagi produk baru tersebut. Dalam hal ini dibutuhkan modal

\footnotetext{
38 Mortazavi S, "Islamic Economics: A Solution for Environmental Protection." (Proceedings of the Conference on Trade. Growth and the Environment, Oxford University, 2004, 2012), 220.

${ }^{39}$ Abul Hassan Dkk, "Islamic Marketing Ethics and Its Impact on Customer Satisfaction in the Islamic Banking Industry," JKAU: Islamic Econ Vol. 21, no. No. 1 (2008): 27-46.

${ }^{40}$ Munib Siddiqui dkk, "Halal Marketing (Islamic Principles of Marketing and Marketing Mix Model in Islam)."

41 Rifda Nabila, "Application of Islamic Business Ethics in Online Selling and Buying Transaction," Indonesian Journal of Islamic Economics Research 1, no. 1 (n.d.): 1-10.
} 
atau biaya pemasaran yang cukup besar disertai dengan perjuangan dan strategi pemasaran khusus agar produk dapat mengena di hati masyarakat.

Oleh karena itu dalam praktiknya pengusaha bisnis Islam dalam melakukan produksi hendaknya sesuai dengan aspek produksi sebagai berikut, pertama, melakukan proses produksi dilandasi dengan niat beribadah kepada Allah yaitu mengaktualisasikan apa yang telah diberikan oleh Allah hanya untuk meraih ridho Allah. Kedua, memanfaatkan potensi yang dimiliki untuk mengolah faktor produksi yang tidak terbatas. Ketiga, melakukan proses produksi tentunya tidak semata mata untuk keuntungan pribadi tetapi lebih kepada memberikan manfaat atas produk yang telah diciptakan guna kemaslahatan bersama. Keempat, pelaku bisnis muslim hendaknya menghindari proses produksi yang mangandung unsur haram, riba, spekulasi dan pasar gelap. ${ }^{42}$ Dalam memasarkan produk baru ini, tentunya dibutuhkan strategi pemasaran yang akan membawa pengaruh besar terhadap penjualan produk karena kesan pertama konsumen dapat menentukan penilaian mereka terhadap citra produk. ${ }^{43}$

Konsep pemasaran dalam Islam mengajarkan tentang pentingnya menerapkan menajemen profesional, yaitu dengan melakukan kegiatan pemasaran yang sesuai dengan ajaran Islam, Karena produk yang diciptakan senantiasa memiliki posisi di pasaran karena banyak diminati konsumen. ${ }^{44}$ Jika kehendak bebas ini sudah diimplemenasikan dalam melakukan proses produksi atau malakukan inovasi produk baru maka akan melahirkan etika didalam menciptakan produk baru dalam karakter pelaku bisnis Islam, tentunya hal ini akan menimbulkan tujuan fundamental dalam ekonomi Islam yaitu kemaslahatan bersama.

4. Analisis tanggung jawab dalam manajemen pemasaran

Bertanggung jawab adalah bertanggung jawab terhadap produk hingga sampai ke tangan konsumen. Oleh karena itu seorang marketing yang menerapkan analisis Tanggung jawab adalah :

a. Bertanggung jawab pada proses distribusi

Dalam hal pengiriman atau distribusi barang yang telah dipesan oleh konsumen. Pengiriman produk harus sesuai waktu yang dijanjikan karena inilah wujud tanggung jawab pelaku bisnis terhadap konsumen. Dalam mendistribusikan produk, Islam sangat menekankan bahwa distributor tidak diperbolehkan bersikap memaksa, menambah beban biaya transportasi dan mengirimkan barang dengan terlambat. Di dalam memberikan pelayanan distribusi produk harus mempertimbangkan bahwa maksimalisasi laba bukanlah hal yang tepat

\footnotetext{
${ }^{42}$ Ermawati Usman, "PERILAKU PRODUSEN DALAM ETIKA BISNIS ISLAM (Suatu Upaya Perlindungan Konsumen)," Jurnal Hunafa Vol. 4, no. No. 3, (2007): 207-16.

${ }^{43}$ Zainal veithzal rivai. Dkk, Islamic Marketing Management "mengembangkan Bisnis Dengan Hijrah Kepemasaran Islami Mengikuti Praktik Rosulullah, .

${ }^{44}$ Hilmiatus Sahla, “Konsep Pemasaran Dalam Perspektif Ekonomi Islam,” Jurnal Pionir Vol. 5, no. N0.2 (2019): 57-61.
} 
untuk mewujudkan kesejahteraan masyarakat. ${ }^{45}$ Untuk memperlancar proses distribusi, Perusahaan harus memilih jaringan distribusi yang efektif agar barang sampai ketangan konsumen tanpa merugikan pesaing bisnis. ${ }^{46}$ Distributor memiliki tanggung jawab kepada : pertama, Allah SWT, karena semua manusia akan dimintai pertanggung jawaban atas apa yang sudah dilakukan di dunia ini. Kedua, konsumen, yaitu tanggung jawab atas sampainya barang tepat waktu dan tepat sasaran. Ketiga, perusahaan, yaitu tanggung jawab menjual semua barang dagangan.

Dalam kerangka etika bisnis Islam tujuan saluran distribusi adalah menciptakan nilai dan mengangkat standart hidup dengan memberikan pelayanan secara etis. $^{47}$

b. Bertanggung jawab terhadap lingkungan sosial sekitar

Bentuk tanggung jawab terhadap lingkungan sekitar dapat diwujudkan dengan cara menunaikan CSR pada bidang kesejahteraan, kesehatan dan pendidikan. Hal ini bertujuan untuk meningkatkan taraf hidup masyarakat sekitar sehingga dampak positif dari adanya perusahaan dapat dirasakan oleh masyarakat sekitar

5. Analisis kebajikan dalam manajemen pemasaran

Makna kebajikan disini adalah berbuat baik atau ikhsan yang dilakukan oleh pelaku bisnis Islam kepada konsumen atau pengguna akhir terhadap produknya. Oleh karena itu seorang marketing yang menerapkan prinsip kebajikan adalah:

a. Berbuat baik atau ikhsan kepada konsumen

Seorang marketing muslim harus memiliki perilaku ikhsan kepada para konsumennya, dengan berperilaku ikhsan maka tujuan kedua belah pihak dapat tercapai dimana tujuan para marketing adalah keuntungan yang bersifat materi sedangkan tujuan dari konsumen adalah terpenuhi kebutuhannya. Perlindungan terhadap konsumen dapat dilakukan dalam 3 tahap, yaitu : Ketik sebelum transaksi jual beli, yaitu melindungi konsumen dari promosi yang tidak benar misal gharar (penipuan terhadap kualitas produk), bay najasi (menyuruh seseorang untuk memuji produk kita) dan tadlish (memaksa konsumen yang minim informasi terhadap produk kita untuk melakukan pembelian). ${ }^{48}$ Ketika transaksi jual beli sedang berlangsung yaitu, melindungi konsumen dari kecurangan atau tipu muslihat saat transaksi berlangsung. Setelah terjadi transaksi yaitu, melindungi konsumen dengan cara memberikan khiyar atau

\footnotetext{
${ }^{45}$ Abuznaid S, . “. Islamic Marketing: Addressing the Muslim Market," An - Najah 26, no. 6 (2012): 14731503.

${ }^{46}$ Zainal veithzal rivai. Dkk, Islamic Marketing Management "mengembangkan Bisnis Dengan Hijrah Kepemasaran Islami Mengikuti Praktik Rosulullah,.

47 Dkk, "Islamic Marketing Ethics and Its Impact on Customer Satisfaction in the Islamic Banking Industry."

${ }^{48}$ Adiwarman A. Karim, Ekonomi Mikro Islami (Depok: PT.RajaGrafindo Persada, 2017).
} 
kesempatan menukar. ${ }^{49}$ Dengan cara ini harapannya adalah tercapainya konsep yang diajarkan oleh ekonomi Islam yaitu keseimbangan, kejujuran dan keharmonisan yang dikemas didalam ajaran Islam melalui Al Quran dan Hadist. ${ }^{50}$

Adapun tujuan dari berbuat kebajikan kepada konsumen adalah menciptakan loyalitas konsumen kepada produk yang kita jual. Loyalitas dalam Islam disebut al wala' yang memiliki makna cinta, mendekati dan mengikuti, oleh karena itu loyalitas konsumen dalam Islam terjadi ketika kegiatan muamalah yang dilakukan kedua belah pihak membawa manfaat bagi masing masing pihak, karena berjalan sesuai dengan nilai syariah. ${ }^{51}$ Mengingat pentingnya implementasi kebajikan dalam manajemen pemasaran maka jika kebajikan benar benar diterapkan pasti akan melahirkan Etika kebajikan kepada konsumen sehingga loyalitas konsumen dapat terwujud.

b. Memiliki kode etik atau norma etika

Dalam melakukan kegiatan pemasaran, terdapat acuan atau pedoman tentang perilaku yang biasa disebut dengan kode etik atau norma etika. Kode etik ini harus dijalankan sebagai pedoman dalam bersikap dan berperilaku dalam menjalankan kegiatan pemasaran (Bodo B. Schlegelmilch Magdalena Oberseder, 2010).

\section{Gambar 1. Implementasi Etika Bisnis Islam dalam Manajemen Pemasaran}

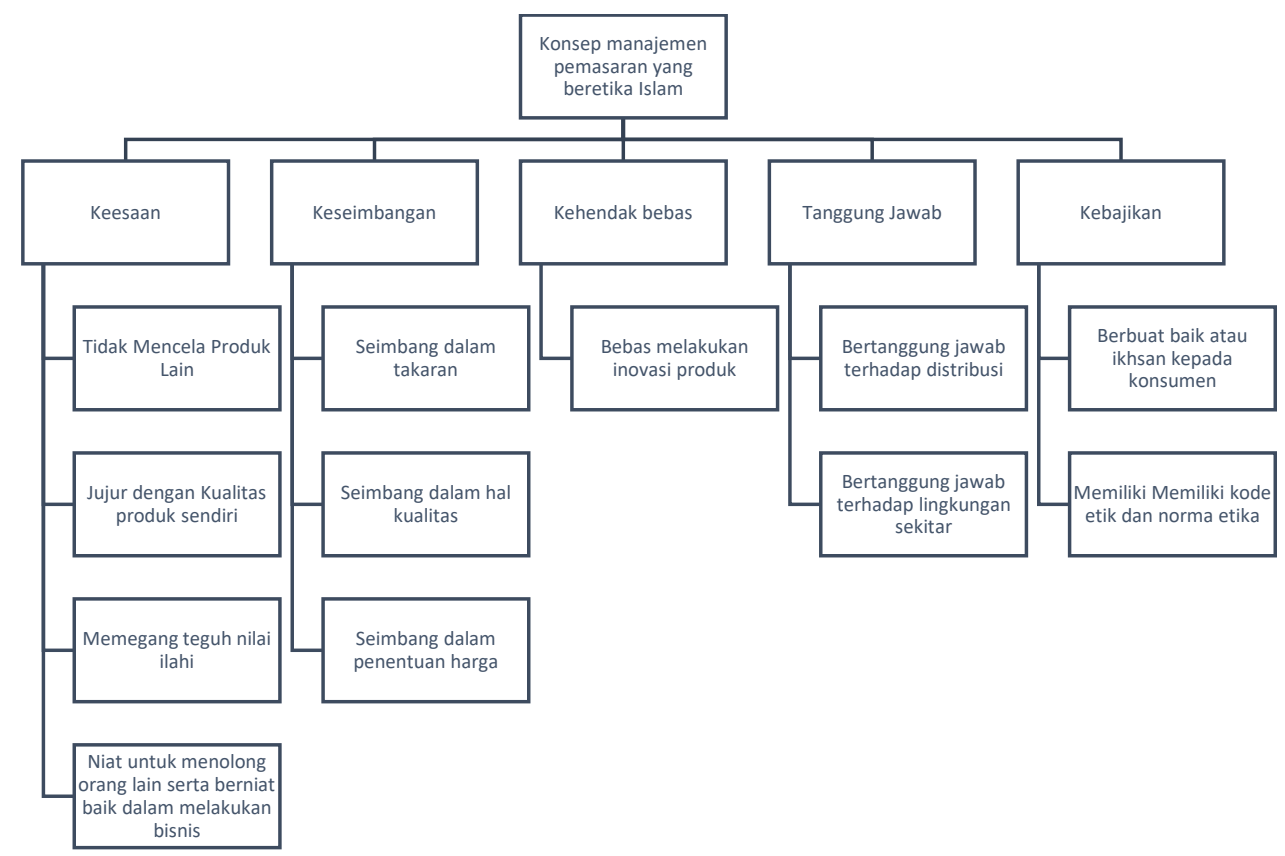

\footnotetext{
${ }^{49}$ Karim.

${ }^{50}$ Permatasari \& usan Endah, “Konsep Kepemilikan Dalam Ekonomi Islam," Ad-Deenar: Jurnal Ekonomi Dan Bisnis Islam 05, no. 01 (2021): 39-54, https://doi.org/10.30868/ad.v5i01.1229.

51 Zuhdan Ady Fataron Mawadah Murtiawati, "The Impact of Product Quality and Service Quality on Consumer Loyalty (a Case Study of Bandeng Rozal in Bandengan Village, Kendal District, Kendal Regency)," Journal of Islamic Economics, Management, and Business Vol. 1, no. No. 1 (n.d.): 47-118.
} 


\section{Penutup}

Begitu sempurna Islam mengajarkan tentang berbisnis salah satunya adalah tentang implementasi etika bisnis Islam, Nilai etik inilah yang mendorong manusia menjadi sosok individu yang mulia dan senantiasa melakukan tindakan yang menyejukkan hati, sebagai abdillah yang seutuhnya. Lima konsep manajemen pemasaran yang beretika Islam diantaranya adalah Keesaan dalam manajemen pemasaran (tidak mencela produk lain, jujur dengan kualitas produk sendiri, memegang teguh nilai ilahi dan memiliki niat mencari untung dan menolong orang lain), Keseimbangan dalam manajemen pemasaran (seimbang dalam timbangan, seimbang dalam menjaga kualitas, seimbang dalam penetapan harga), Kehendak bebas dalam manajemen pemasaran (bebas dalam melakukan inovasi produk yang sesuai dengan islam), Tanggung jawab dalam manajemen pemasaran (bertanggung jawab dalam hal distribusi atau mengirimkan produk ke tangan konsumen serta bertanggung jawab terhadap lingkungan sekitar), Kebajikan dalam manajemen pemasaran (berbuat baik dan ikhsan kepada konsumen serta memiliki kode etik dan norma etika). Jika konsep implementasi etika bisnis ini diterapkan dalam kegiatan bisnis maka bisnis tersebut akan mewujudkan kehidupan bermuamalah masyarakat yang adil sejahtera dan makmur sehingga sesuai dengan tujuan Islam turun ke bumi yaitu rohmatan lil alamin.

Dari adanya konsep pemasaran yang beretika Islam seperti di atas, maka disarankan dapat menjadi bahan penelitian empiris untuk peneliti selanjutnya baik penelitian tentang pemasaran yang beretika pada perusahaan atau lembaga nirlaba lainnya.

\section{DAFTAR PUSTAKA}

Ahmad Hulaimi dkk. "Etika Bisnis Islam Dan Dampaknya Terhadap Kesejahteraan Pedagang Sapi." JEBI (Jurnal Ekonomi Dan Bisnis Islam) Volume 2, no. Nomor 1 (2017): 17-32.

Djakfar, H. Etika Bisnis: Menangkap Spirit Ajaran Langit Dan Pesan Moral Ajaran Bumi. Jakarta: Penebar PLUS+., 2012.

Dkk, Abul Hassan. "Islamic Marketing Ethics and Its Impact on Customer Satisfaction in the Islamic Banking Industry." JKAU: Islamic Econ Vol. 21, no. No. 1 (2008): 2746.

Dkk, Isnaini harapan. Hadis Hadis Ekonomi. Jakarta: kencana, 2015.

Endah, Permatasari \& usan. "Konsep Kepemilikan Dalam Ekonomi Islam." Ad-Deenar: Jurnal Ekonomi Dan Bisnis Islam 05, no. 01 (2021): 39-54. https://doi.org/10.30868/ad.v5i01.1229.

Erly Juliyani. "Etika Bisnis Dalam Perspektif Islam." Jurnal Ummul Qura Vol VII, no. No.1 (2016): 63-74.

Farma, Junia, and Khairil Umuri. "Implementasi Etika Bisnis Islam Dalam Strategi Promosi Produk Asuransi Takaful." Cakrawala: Jurnal Studi Islam 15, no. 1 (2020): 19-29. https://doi.org/10.31603/cakrawala.v15i1.3268. 
Galuh Anggraeny. "Pembelajaran Dan Implementasi Etika Bisnis Islam: Studi Pada Mahasiswa Akuntansi Syariah IAIN Surakarta." Academica Vol. 1, no. No. 2 (2017): 231-42.

Hanafi Amrani. "Perlindungan Konsumen Terhadap Praktik Bisnis Curang Dan Upaya Penegakannya Melalui Sarana Hukum Pidana." Negara Hukum 6, no. 2 (2015): 188.

Harahap, Sofyan. Etika Bisnis Dalam Perspektif Islam. Jakarta: Salemba Empat, 2011.

Hilmiatus Sahla. “Konsep Pemasaran Dalam Perspektif Ekonomi Islam." Jurnal Pionir Vol. 5, no. N0.2 (2019): 57-61.

Karim, Adiwarman A. Ekonomi Mikro Islami. Depok: PT.RajaGrafindo Persada, 2017.

Lalu Muh Shabiran dkk. "Etika Bisnis Pedagang Pada Jual Beli Telepon Genggam Bekas Ditinjau Dari Perspektif Ekonomi Islam Di Kecamatan Selong Kabupaten Lombok Timur." Iqtishoduna Vol. 6, no. No. 2 (2017): 190-221.

Mawadah Murtiawati, Zuhdan Ady Fataron. "The Impact of Product Quality and Service Quality on Consumer Loyalty (a Case Study of Bandeng Rozal in Bandengan Village, Kendal District, Kendal Regency)." Journal of Islamic Economics, Management, and Business Vol. 1, no. No. 1 (n.d.): 47-118.

Moh. Toriquddin. "Etika Pemasaran Perspektif Al-Qur'an Dan Relevansinnya Dalam Perbankan Syari'ah." De Jure, Jurnal Syariah Dan Hukum Volume 7, no. Nomor 2 (2015): 116-25.

Mortazavi S. "Islamic Economics: A Solution for Environmental Protection.," 220. Proceedings of the Conference on Trade. Growth and the Environment, Oxford University, 2004, 2012.

Mubarok, Nurul dan Eriza Yolanda Maldina. "Strategi Pemasaran Islami Dalam Meningkatkan Penjualan Pada Butik Calista." I-Economic Vol.3, no. No 1 (2017): 73-92.

Muhammad. Etika Bisnis Islam. yogyakarta: UPP AMP YKPN, 2002.

muhammmad Ismail Yusanto dan Muhammad Karebet Widjajakusuma. Menggagas Bisnis Islam. Jakarta: Gema Insani, 2002.

Munib Siddiqui dkk. "Halal Marketing (Islamic Principles of Marketing and Marketing Mix Model in Islam)." Advances in Islamic Business Vol 3, no. No 5 (2017): 28998.

Muslich. Bisnis Syariah. Perspektif Muamalah Dan Manajemen. Yogyakarta: UPP STIM YKPN, 2007.

Nabila, Rifda. "Application of Islamic Business Ethics in Online Selling and Buying Transaction." Indonesian Journal of Islamic Economics Research 1, no. 1 (n.d.): 110.

Nana Herdiana Abdurrahman. Manajemen Bisnis Syariah \& Kewirausahaan. Bandung: CV.Pustaka Setia, 2013. 
Perry, A. \& Hammond. "N. Systematic Reviews: The Experience of a PhD Student." Psychology Learning and Teaching 2, no. 1 (2002).

Ramdania, Wida. "Etika Bisnis Islam Pada Perilaku Pemasaran Dan Kepuasan Konsumen." Asy-Syari'ah 22, no. 2 (2021): 275-90. https://doi.org/10.15575/as.v22i2.8259.

Riyanto Sofyan. Bisnis Syariah Mengapa Tidak. Pengalaman Penerapan Pada Bisnis Hotel. Jakarta: PT. Gramedia Pustaka Utama), 2011.

S, Abuznaid. . ". Islamic Marketing: Addressing the Muslim Market." An - Najah 26, no. 6 (2012): 1473-1503.

Siswanto. "Systematic Review Sebagai Metode Penelitian Untuk Mensintesis HasilHasil Penelitian." Buletin Penelitian Sistem Kesehatan 13, no. 4 (2010).

Siti Nur Latifah. "Pengaruh Penerapan Etika Bisnis Muhammad Saw Terhadap Customer Retention Dan Dampaknya Terhadap Peningkatan Pendapatan Internal Stakeholders, (STUDI KASUS PADA UNIT USAHA PENJUALAN DAN JASA PENGGILINGAN DAGING PELITA JAYA JEMBER)." Iqtishoduna: Jurnal Ekonomi Islam Vol. 8, no. No. 1 (2019): 97-140.

Syaeful Bakhri, Leliya dan Latip Purnama. "TINJAUAN ETIKA BISNIS ISLAM DALAM STRATEGI PEMASARAN HOME INDUSTRI TAHU SARI RASA." Al-Mustashfa Vol. 3, no. No. 2 (2018): 284-99.

Usman, Ermawati. "PERILAKU PRODUSEN DALAM ETIKA BISNIS ISLAM (Suatu Upaya Perlindungan Konsumen)." Jurnal Hunafa Vol. 4, no. No. 3, (2007): 207-16.

Zainal veithzal rivai. Dkk. Islamic Marketing Management "mengembangkan Bisnis Dengan Hijrah Kepemasaran Islami Mengikuti Praktik Rosulullah,. Jakarta: PT Bumi Aksara, 2016.

Zarrad, Houda dan Mohsen Debabi. "ISLAMIC MARKETING ETHICS: A LITERATURE REVIEW." International Journal of Management Research \& Review 5, no. 2 (2015): 60-66. 